MICHAEL L. WACHTER

University of Pennsylvania

\title{
The Wage Process: An Analysis of the Early 1970s
}

SiNCE 1968, wages have been increasing at a fairly steady rate averaging 6 percent annually. In 1969-70, the question was why wages continued to increase so rapidly during a recession. Two hypotheses were offered to explain this puzzle: first, that demographic changes in the labor force had caused the measured unemployment rate to overstate the ease of the labor market; and second, that an increase in inflationary expectations had adversely shifted the inflation-unemployment tradeoff. ${ }^{1}$ In 1973, many economists were puzzled about why wages were increasing as slowly as 6 percent, especially given the very rapid increases in consumer prices. In 1974:2, however, the six-year wage plateau was exceeded and the rate of wage increase jumped to 9.6 percent.

Note: I am indebted to the National Science Foundation and the National Institutes of Health for research support, and to Princeton University, with which I was associated when much of this work was done. Valuable comments were provided by Albert Rees, Stephen A. Ross, Susan M. Wachter, and members of the Brookings panel. I am grateful to James Orr for excellent research assistance.

1. See the papers by Robert J. Gordon, "Inflation in Recession and Recovery," Brookings Papers on Economic Activity (1:1971), pp. 105-58, and "Wage-Price Controls and the Shifting Phillips Curve," BPEA (2:1972), pp. 385-421; and by George L. Perry, "Changing Labor Markets and Inflation," BPEA (3:1970), pp. 411-41. Theoretical background for the expectational model, in an accelerationist framework, is provided in Edmund S. Phelps and others, Microeconomic Foundations of Employment and Inflation Theory (Norton, 1970). 
This paper offers an explanation for recent wage developments and current wage prospects and, in particular, examines the lack of responsiveness of wages in the short run to anti-inflation policies. Wages are approached from three directions. The first approach involves an inspection of relative wages among industries. Many economists have argued that when the traditional relationships among industry wages shift, the attempt to restore customary differentials can cause upward pressure on wages. An analysis of relative wages also identifies the contribution that individual sectors make to particular problems. The second approach concerns the recent major collective bargaining settlements and their implications for near-term wage trends. Specific attention is paid to the pattern emerging from the steel settlement and to the spread of escalator clauses. The third approach uses a simplified wage equation to forecast the near-term outlook for wage inflation. ${ }^{2}$ The wage equations estimated here have a decidedly accelerationist look. If long lags are permitted between price and wage adjustments, the coefficient on the long-run price term is close to unity.

As a consequence of the highly structured and institutionalized nature of the labor market, wages respond with a relatively long lag to their economic determinants. The result is that the ability of government policy to influence wage inflation over short intervals is seriously circumscribedwhether it relies on fiscal or monetary tools or on wage-price controls. Policy swings of the "stop-go" variety are unlikely to reduce the inflation rate. Due to the length of the contract period, as well as the nonlinear response of wages to unemployment, a policy aimed at causing sharp but deep downturns is probably less efficient in controlling inflation than one aimed at shallow but longer intervals of slow real growth.

\section{Relative Wages}

In a study of the overall wage outlook, relative or interindustry wages are of interest because distortions in traditional relationships may cause upward pressure on wages.

As a starting point for an analysis of interindustry wages and as a method of defining the traditional wage structure, I have reestimated my inter-

2. The specification of the Phillips curve used in this paper and its advantages for forecasting purposes are discussed in the section on wage equations. 
Figure 1. Coefficient of Variation of Interindustry Wages in Manufacturing, Actual and Predicted, 1947-74

\section{Coefficient of variation, $\mathrm{CV}$}

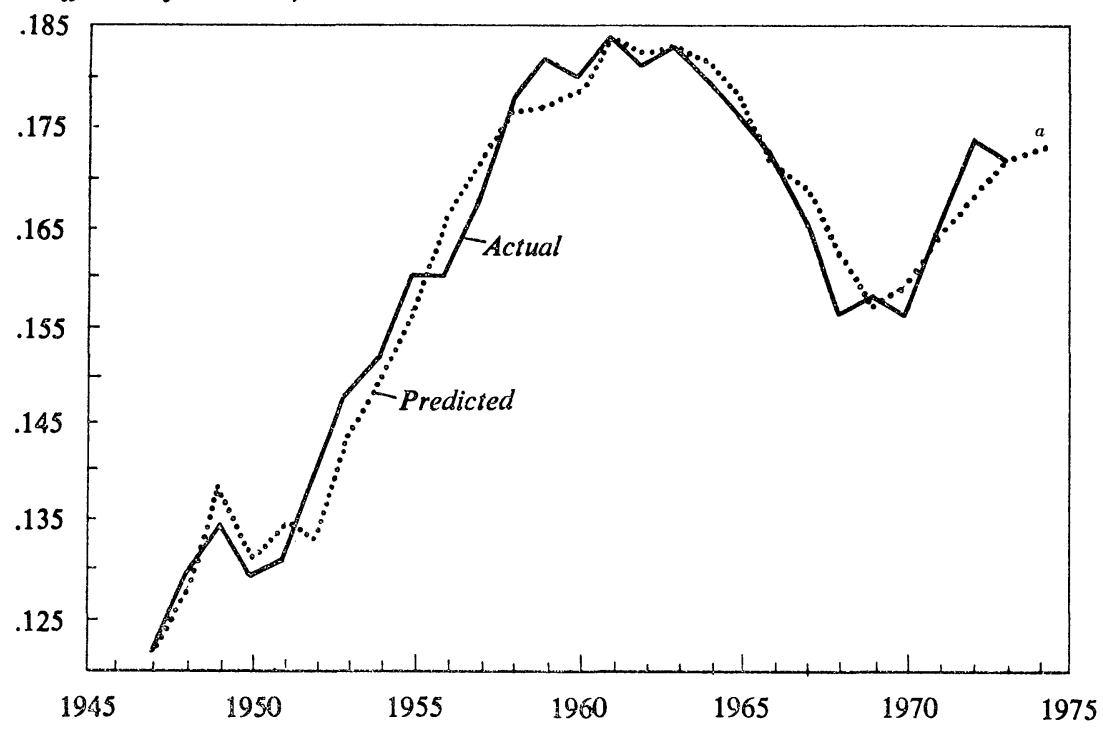

Sources: Equation for $C V$, the coefficient of variation, discussed in the text; official data on the consumer price index; unemployment rates and wages from Current Wage Developments, various issues.

a. The value for 1974 is a projection based on data available through the first half of the year.

industry wage equation for manufacturing for the period 1947-73 using annual data. ${ }^{3}$ The paths of the predicted and actual values of the coefficient of variation of interindustry wages in manufacturing $(\mathrm{CV})$, the dependent variable, are plotted in Figure 1. The equation is of the form

$$
\begin{aligned}
& C V=0.2253-0.3319 \dot{P}-0.2662 U^{-1}-0.0040 G+0.0300 T-0.0181 K \text {, } \\
& \text { (21.4) } \\
& \bar{R}^{2}=0.9619 ; \text { Durbin-Watson statistic }=1.7 \text {. }
\end{aligned}
$$

where $U$ is the unemployment rate, $\dot{P}$ is the rate of inflation as measured by the consumer price index, $G$ and $K$ are dummies for the guidepost and

3. Interindustry wages within manufacturing are used because of the relatively high quality of the data (the specific series is average hourly earnings excluding overtime on the two-digit level of the standard industrial classification) and the good mix of high- and low-wage industries. The coefficient of variation is constructed as an unweighted average of the twenty-one manufacturing industries in the SIC. See Michael L. Wachter, "Cyclical Variation in the Interindustry Wage Structure," American Economic Review, Vol. 60 (March 1970), pp. 75-84. 
Korean War periods, respectively, and $T$ is a time trend. The numbers in parentheses are $t$-statistics. The equations are estimated using Almon lags, and the coefficients shown are the sum of the weights. The lags are quite long; the average lags are approximately three years and the full lags are five years. ${ }^{4}$ The major insight from this approach is that the traditional interindustry wage structure varies systematically over the cycle. The reason is rooted largely in the fact that the high-wage sectors of the economy (which are largely unionized) have a longer planning or contract period than the low-wage, more competitive, sectors. The planning or contract period is the interval over which the wage of the firm, including guaranteed periodic increases, is fixed or predetermined; it generates both lags of adjustment, equal to the length of the contract, and lags due to expectational effects. As a consequence of the longer forecasting horizon of the high-wage sectors, they tend during periods of historically low unemployment and high inflation to underestimate the economy-wide rate of wage change with the result that the wage dispersion narrows. (Conversely, it widens when labor markets are slack..$^{5}$ )

The period of interest can be divided into three short intervals: the precontrols period, 1969-71; Phases I and II; and finally, Phases III and IV.

4. Since this equation is described elsewhere, I will not go into a detailed exposition here. See ibid., and Michael L. Wachter, "Phase II, Cost-Push Inflation, and Relative Wages," American Economic Review, Vol. 64 (June 1974), pp. 482-91.

5. Throughout the paper I use the terms "high-wage sector" and "unionized sector" interchangeably. There are, however, differences and the theory relates more directly to high-wage industries. Specifically, in some unionized industries the union is weak, largely where the product market is competitive and national in scope. For a discussion of this point, see Harold M. Levinson, "Unionism, Concentration, and Wage Changes: Toward a Unified Theory," Industrial and Labor Relations Review, Vol. 20 (January 1967), pp. 198-205. Similarly some high-wage industries, particularly those whose product market is noncompetitive, are not unionized. A discussion of why noncompetitive high-wage industries may prefer a planning period similar to the fixed-contract period is contained in Stephen A. Ross and Michael L. Wachter, "Wage Determination, Inflation, and the Industrial Structure," American Economic Review, Vol. 63 (September 1973), pp. 675-92.

An additional explanation for cyclical variation in the interindustry wage structure is that the desired wage premium of the high-wage sector may vary over the cycle. See, for example, the work of John T. Dunlop, Wage Determination Under Trade Unions (Macmillan, 1944); Charles C. Holt, "Job Search, Phillips' Wage Relation, and Union Influence: Theory and Evidence," in Phelps and others, Microeconomic Foundations; and Albert Rees, The Economics of Trade Unions (University of Chicago Press, 1962). The timing problem, introduced by the existence of fixed-term wage contracts, is stressed by H. G. Lewis, Unionism and Relative Wages in the United States (University of Chicago Press, 1963). 
The precontrols period was marked by rapidly increasing wages, with the high-wage, unionized sectors receiving by far the largest increases. This development is reflected in the relatively large first-year union-wage adjustments shown in Table 1, which also gives life-of-contract wage adjustments. For comparison, Table 2 shows average hourly earnings in various industries. The widening of the wage structure, however, should be attributed not to cost-push inflation but to the cyclical phenomenon traditionally associated with rising unemployment. Specifically, as Figure 1 illustrates, the wage structure among manufacturing industries narrowed during the 1960s as the high-wage sector consistently underestimated the tightness in the labor market and the rate of inflation during the contract period. After erring on the low side during the 1960s, the high-wage sectors began to catch up as contracts expired during the years 1969-71. Furthermore, by projecting into the early 1970s the tight labor markets of the late 1960s, the high-wage sectors overestimated the overall rate of wage change. The widening of the wage structure in this period, as indicated in Figure 1, was consistent with past cyclical fluctuations in relative wages.

Similar results appear when the analysis is extended to nonmanufacturing industries. The two possible exceptions are municipal government

Table 1. Annual Rate of Change in Wages in Major Collective Bargaining Settlements, First Year and Life of Contract, 1968-1974:2

Percent

\begin{tabular}{|c|c|c|c|c|c|c|c|c|}
\hline $\begin{array}{c}\text { Industry and } \\
\text { measure of change }\end{array}$ & 1968 & 1969 & 1970 & 1971 & 1972 & 1973 & $1974: 1^{\mathrm{a}}$ & $1974: 2^{\mathrm{a}}$ \\
\hline \multicolumn{9}{|l|}{ All industries } \\
\hline First year & 7.4 & 9.2 & 11.9 & 11.6 & 7.3 & 5.8 & 6.2 & 9.2 \\
\hline Life of contract & 5.9 & 7.6 & 8.9 & 8.1 & 6.4 & 5.2 & 5.3 & 7.4 \\
\hline \multicolumn{9}{|l|}{ Manufacturing } \\
\hline First year & 7.0 & 7.9 & 8.1 & 10.9 & 6.6 & 5.9 & 6.1 & n.a. \\
\hline Life of contract & 5.2 & 6.0 & 6.0 & 7.3 & 5.6 & 4.9 & 4.9 & n.a. \\
\hline \multicolumn{9}{|l|}{ Nonmanufacturing } \\
\hline First year & 7.8 & 10.8 & 15.2 & 12.2 & 7.8 & 5.7 & 6.3 & n.a. \\
\hline Life of contract & 6.5 & 9.3 & 11.5 & 8.9 & 6.9 & 5.3 & 5.5 & n.a. \\
\hline \multicolumn{9}{|l|}{ Construction } \\
\hline First year & 8.7 & 13.1 & 17.6 & 12.6 & 6.9 & 5.0 & 5.2 & n.a. \\
\hline Life of contract & 8.6 & 13.1 & 14.9 & 10.8 & 6.0 & 5.1 & 4.8 & n.a. \\
\hline
\end{tabular}

Source: Current Wage Developments, various issues. a. Quarterly change at annual rate; preliminary. n.a. Not available. 
Table 2. Annual Rate of Change from Previous Year in Average Hourly Earnings, Private Nonfarm Economy, by Sector, 1968-74a

Percent

\begin{tabular}{|c|c|c|c|c|c|c|c|c|}
\hline Sector & 1968 & 1969 & 1970 & 1971 & 1972 & 1973 & $1974: l^{\mathrm{b}}$ & $1974: 2^{\mathrm{b}}$ \\
\hline \multicolumn{9}{|l|}{ Total private nonfarm } \\
\hline Current dollars & 6.6 & 6.6 & 6.7 & 7.0 & 6.3 & 6.3 & 6.0 & 9.6 \\
\hline 1967 dollars $^{\mathrm{c}}$ & 2.3 & 1.2 & 0.7 & 2.6 & 3.0 & 0.0 & -5.6 & n.a. \\
\hline Mining & 5.6 & 7.7 & 5.8 & 5.7 & 7.5 & 7.2 & 13.3 & 12.9 \\
\hline Contract construction & 7.1 & 8.8 & 9.3 & 8.5 & 6.4 & 6.6 & 5.0 & 8.5 \\
\hline Manufacturing & 6.2 & 6.0 & 6.2 & 6.6 & 6.2 & 5.9 & 6.0 & 11.2 \\
\hline $\begin{array}{c}\text { Transportation and } \\
\text { public utilities }\end{array}$ & 5.5 & 6.4 & 6.1 & 9.2 & 10.5 & 8.5 & 5.3 & 4.3 \\
\hline $\begin{array}{l}\text { Wholesale and retail } \\
\text { trade }\end{array}$ & 7.2 & 6.4 & 6.1 & 5.9 & 5.2 & 6.1 & 6.7 & 10.0 \\
\hline $\begin{array}{l}\text { Finance, insurance, and } \\
\text { real estate }\end{array}$ & 5.8 & 6.0 & 6.0 & 6.6 & 5.2 & 5.2 & 3.9 & 7.8 \\
\hline Services & 6.6 & 6.9 & 7.2 & 7.3 & 5.6 & 5.8 & 7.8 & 10.0 \\
\hline
\end{tabular}

Source: Current Wage Developments, various issues.

a. Adjusted for overtime (in manufacturing only) and for interindustry employment shifts.

b. Quarterly change at annual rate; preliminary.

c. As deflated by the CPI.

n.a. Not available.

and contract construction. The rate of increase of average hourly earnings in construction has consistently outpaced that in the economy as a whole, a secular trend that became even more pronounced in 1969-71. ${ }^{6}$ The widening of wage differentials for municipal employees is a recent phenomenon and may reflect a once-and-for-all premium from the spread of unionization in this sector. With these two exceptions, interindustry wages have been in the traditional alignment over the recent period.

Wage controls exercised under Phases I and II seem to have endorsed this pattern of wage settlements, as those who served on the Pay Board have testified. First, although the Pay Board had a strategy aimed at affecting bargaining situations involving large unions, "Phase II caught the tail end of a catch-up wage round, and Pay Board policies permitted the adjust-

6. Other factors besides cost-push pressure could explain the upward spiral of relative wages in construction. An explanation based on changes in the mix of skilled and unskilled workers seems implausible because wage increases for both groups in this industry have outstripped wage changes elsewhere. Studies that take note of the recent slowdown in the size of wage increases in construction suffer from their concentration on increases rather than levels. 
ment to take place." " Second, "the industries that obtained approvals for higher increases - the 'extractive' sector (chiefly coal mining) and transportation (railroads, longshore, trucking, and postal services)-are highly unionized." The influence of Phase II is shown graphically in Figure 1, where the residual for 1972 is sharply positive, indicating that the highwage differential was well above its predicted value. Hence, if anything, Phase II seems to have allowed the high-wage sectors to increase their wage premium in 1972 beyond the level predicted by the existing labor market conditions.

The drop in the magnitude of wage settlements between 1971 (which was mostly a precontrols year) and 1972 (when controls were in effect) was actually quite moderate in terms of provisions for the entire life of the contract. The big decline occurs in "first-year adjustments." The timing of contract settlements probably explains these developments. Industries whose settlements came due in 1972 had previously negotiated wages in 1969, the first catch-up year after the 1961-68 narrowing in differentials. Hence, these industries had already begun to reestablish their more traditional differentials. On the other hand, the wage bargains in 1971 for industries on three-year contracts were the initial attempt to redress the 1961-68 decline; hence the front loading of the 1971 settlements. Furthermore, on the basis of figures relating to wages over the life of the contract, unions that settled in 1968 and 1971, and in 1969 and 1972, received the same average 14 percent increase over the two contracts. (In fact, the same increase is apparent for the unions in the 1970-73 contract cycle.)

For the year 1973 the residual of the relative wage equation returned to zero, so that whatever distortions occurred in 1972 were largely undone. Projections for 1974 indicate that relative wages are again on target, in terms of their traditional position over the business cycle.

It has been suggested that wage "distortions," or changes in interindustry wage differentials, may be a factor determining the rate of wage inflation. ${ }^{9}$ The model of relative wages suggests that, rather than being an independent

7. Daniel J. B. Mitchell and Arnold R. Weber, "Wages and the Pay Board," in American Economic Association, Papers and Proceedings of the Eighty-sixth Annual Meeting, 1973 (American Economic Review, Vol. 64, May 1974), p. 90.

8. Daniel J. B. Mitchell, "Phase II Wage Controls," Industrial and Labor Relations Review, Vol. 27 (April 1974), p. 361.

9. See, for example, Arnold H. Packer and Seong H. Park, "Distortions in Relative Wages and Shifts in the Phillips Curve," Review of Economics and Statistics, Vol. 55 (February 1973), pp. 16-22; and Wachter, "Cyclical Variation." 
cause of inflation, distortions of usual differentials are determined coincidentally with wage inflation by current and lagged values of the unemployment rate and the rate of price inflation. ${ }^{10}$ The coefficient of variation $(\mathrm{CV})$, as a measure of wage dispersion, may indeed help to explain wage inflation, but only because it reflects previous values of price changes and unemployment that determine current rates of wage increase. Hence, if $C V$ is used as an explanatory variable in a wage equation, it should be interpreted as a proxy, representing the lagged response of wage changes to labor market conditions and price changes.

The evidence suggests that there is no backlog of compressed wage differentials in early 1974 that will need to be expanded in late 1974 and 1975 as long as price inflation and conditions in the labor market remain unchanged. First, the wage structure is wider than it was in 1969-70 so that the high-wage sectors have had their catch-up round of increases; second, the relative-wage equation is on target. The major potential trouble point is contract construction which, contrary to the relative-wage equation, had wage changes greater than those in other sectors before 1972. The very high unemployment rates in this sector as well as the recent surge in nonunion construction, however, should dampen wage increases and might finally cause some narrowing of the relation with other wages.

\section{Wage Contract Settlements}

The developments during the 1969-73 period do not mean that widening in relative wages cannot occur if labor markets weaken. Wage differentials are on target in early 1974, but the expected differential will widen if unemployment rises. The opening wedge of such a widening can be seen in the can, aluminum, and steel settlements of 1974 . The wage pattern established in these agreements will continue to influence both relative wages and the absolute rate of wage change until those settlements expire in 1977. ${ }^{11}$

10. For a theoretical development of this model, see Ross and Wachter, "Wage Determination."

11. The following discussion of wage settlements should not, however, be interpreted as a kind of union-wage model of overall wage determination. Rather, the implications of current wage contracts should be viewed in the context of the relative-wage equation. Current and lagged values of unemployment and inflation determine the current bargaining packages and, as labor market conditions evolve, the path of relative wages and the rate of wage inflation. 
The current wage pattern, although generally heralded as quite moderate, should be so classified only on the assumption that the economy will be operating near full capacity over the next three years, contrary to the verdict of most current economic forecasts. The steel settlement provides an example of a contract that can increase differentials in the face of higher unemployment and lower price inflation. The settlement has been priced in the following manner $:^{12}$

Deferred increases under the preceding contract

$\$ 0.39$

Basic wage increase spread over three years

0.84

Basic fringe increase spread over three years

0.92

Escalator increases assuming a 7 percent annual increase in the consumer price index

Total

The American Iron and Steel Institute estimates that the base hourly rate for wages plus fringes amounted to $\$ 8.40$ in February $1974 .{ }^{13}$ On this base, the three-year increase is 38.7 percent. Omitting the fringe increase, which is difficult to price accurately, and using a base hourly wage rate of $\$ 5.90$, the three-year increase is 39.5 percent. Without the deferred increase of $\$ 0.39$, the overall wage gain falls to 33 percent. The escalator provision allows a $1 \phi$ raise for every 0.3 point change in the CPI. This amounts to approximately 80 percent protection against inflation and, by construction, the rate of protection rises slowly with increases in consumer prices. The basic wage increase of $\$ 0.84$ amounts to a 14 percent increase. With escalator protection of 80 percent this basic wage increase should allow a real wage increase of at least 3 percent per year evaluated at any point in the range of currently foreseeable rates of inflation.

Given conditions at the time the settlement was reached-the economic boom in the steel industry and other primary goods processors, the relatively stable economy, and the widespread expectation that the battle against inflation would be deserted to secure low unemployment at election time - the settlement was certainly generous, but not unreasonable. As all economic forecasters know, the current period has been a difficult one to predict. In early 1974 negotiators and economists alike were forecasting a strong economy over the near future. If the nation sustains a prolonged slowdown, however, steel and the other industries that have settled on this

12. These estimates were provided by George L. Perry. With appropriate assumptions, similar kinds of numbers can be extracted from data in Current Wage Developments.

13. See Monthly Labor Review, Vol. 97 (June 1974), pp. 68-70. 
package may find it costly indeed. For example, if a deep recession were to develop and succeed in reducing the inflation rate to 3 percent, the steel settlement would still lead to an increase in wage rates of approximately 22 percent over three years (excluding the deferred increases). Hence, although the escalator clause ensures some flexibility in the wage settlement, the protected increase in real wages is well above the historical rate observed during recessions. As in previous downturns, rising unemployment and declining inflation will widen the interindustry wage structure as increases in the more competitive industries become smaller while the highwage sectors are locked into more generous contracts.

At present it appears that, with two exceptions, the steel contract will set the pace for other settlements due to expire in 1974 and early $1975 .{ }^{14}$ The first exception is the coal industry, where the competitive pressures inherent in its unique current position may well mean a wage settlement higher than the prevailing pattern. The size of the settlement will largely reflect the rapid rise in the demand for coal workers operating against a labor supply that is likely to be inelastic as a consequence of the nature of the work. Second, the railroad contract remains, as always, unpredictable. As a consequence of their uniqueness, however, neither of these two negotiations is likely to have important spillover effects on wages within the unionized sector. ${ }^{15}$

Although the steel pattern may represent the upper bound of wage contracts, a particularly strong point is the degree of inflation protection built into the escalator provision. In other contracts the level of protection is generally lower. If the next few years witness much less inflation, the gap between the steel pattern and other contracts will be reduced. The wage data of Table 1 exclude escalator increases that are not automatically guaranteed..$^{16}$ Hence, they represent the zero-inflation case, and set the lower bound of major wage settlements in the unionized sector. Unfortunately, the available data do not permit an accurate estimate of

14. Most of the major contracts for 1974 have already been negotiated. The same was true at this time in 1971, when Phase I was introduced.

15. It is obvious that strikes in either of these industries could have a severe impact on the economy.

16. Guaranteed escalator increases are a type of deferred increase in that they automatically come into effect regardless of the rate of inflation. These increases are considered part of the increases called for by the escalator formula when the inflation rate is greater than zero. 
deferred wage increases, including escalators, in the union contracts that will be in force over the next few years. ${ }^{17}$

Unions (or the high-wage sectors) have a major impact on the inflation problem in that they serve to lock important sectors of the economy into a given wage pattern that may run counter to government goals or to strong cyclical swings in the economy. Whereas the discrete timing works on the side of wage restraint when inflationary pressures are building up (as in 1965-69 and 1972-73), it prevents a prompt slowdown in wage inflation when the government moves into the "stop" phase of the "stop-go" syndrome. ${ }^{18}$ These factors, as well as the potential for important discontinuities that can arise from the formation of expectations, the bunching of contracts in certain years, and spillovers among contracts, suggest that attempts to bring down the inflation rate will cost less if pursued gradually, over a relatively extended period. ${ }^{19}$

Assuming the economy does slow down, relative wages will continue to widen as wage changes in the more rapidly responding competitive sectors slow while those in the high-wage sectors remain at the higher level dictated by their contracts. Without escalator clauses, the current pattern would pose a greater problem for policymakers; presumably the fixed wage gains would have been larger and there would be considerably more pressure for monetary and fiscal policy simply to validate the higher expected inflation rate. The potential problem in the current pattern, even including the escalator clauses, is that the protected increases in real wages,

17. The most current analysis on the impact of escalator clauses is Jerome M. Staller and Loren M. Solnick, "Effect of Escalators on Wages in Major Contracts Expiring in 1974," Monthly Labor Review, Vol. 97 (July 1974), pp. 27-32. The new series of the Bureau of Labor Statistics on the "effective date," as distinct from the date of negotiation, of wage changes does not solve the problem. With escalator clauses being rapidly strengthened and extended to new workers, past measures of aggregate escalator increases understate what is likely to occur in the future.

18. This point is analyzed in some detail in Ross and Wachter, "Wage Determination."

19. Although a gradual and prolonged slowdown in real growth may be more effective than a steep and short recession, the burden of unemployment that the two impose may fall on different groups. In a sustained period of slow real growth (below the potential growth rate), the "bumping" process, in which the skilled workers displaced in a particularly hard-hit industry replace the unskilled workers in a less vulnerable industry, will have more time to evolve. These distributional questions must be considered and a mechanism for spreading the sacrifices among all members of society developed. The lack of such a mechanism is a major reason why previous anti-inflation battles have not been sustainable. 
which are not responsive to interperiod changes in economic conditions, will make it more difficult to slow inflation and will impose what will appear to be a "cost-push" element stemming from wages in the unionized sectors.

\section{Wage Equations}

This section presents wage equations using the official unemployment and inflation rates as independent variables, in order to forecast near-term changes in wage inflation. The previous sections stressed the lags in the wage determination process. First, with labor unions and long-term fixed contracts, lags of adjustment of three years are likely. Second, the relativewage equation calculated mean lags of three years with significant weights extending out five years. Most previously estimated wage-change equations, on the other hand, embody only short lags, and some use only contemporaneous variables or variables lagged only one quarter. ${ }^{20}$ The question of long lags versus almost immediate adjustment of wages has important implications for policy to counter inflation.

For purposes of forecasting wages, the official unemployment rate and some inflation rate as independent variables have several advantages over more complicated specifications that include constructed variables such as hidden unemployment or unemployment dispersion. First, these constructed variables are often themselves functions of official unemployment and inflation rates. Hence, the equation used here may be viewed as a quasi reduced-form approach. Second, the literature holds no consensus on the form of at least some of these functional relationships. For example, some authors view short-run fluctuations in labor force participation as dependent on a distributed lag of official unemployment; while others,

20. A step toward reconciling these differences is found in Gordon, "Inflation in Recession and Recovery," and "Wage-Price Controls." In some respects, the long lags are consistent with, and provide a complementary interpretation to, Perry's "habitual" rate of inflation-see "Changing Labor Markets and Inflation"-and Sidney Weintraub's "exogenous" wage variable-see Some Aspects of Wage Theory and Policy (Chilton, 1963). The lags are also consistent with an expectational framework-for example, Phelps and others, Microeconomic Foundations; however, much of the expectational literature has been developed within the confines of a competitive model. The analysis of this paper stresses the role of adjustment as well as expectational lags operating within an institutional framework. 
including myself, see relative wages and money illusion as the determining influences. The result is that constructed variables may confound unemployment and inflation effects so that the elasticities of wage changes with respect to the two official variables may be difficult to disentangle from one another. ${ }^{21}$

\section{PRICE AND UNEMPLOYMENT VARIABLES}

Table 3 presents estimates from several wage equations. For the price term, the consumer price index $(C P I)$, the private nonfarm deflator $(P N F D)$, and the private consumption deflector $(P C O N)$ were tested. The $P N F D$ performed marginally better than the $P C O N$ and significantly better than the $C P I$. The variable was entered, without experimentation, with a lag of twelve quarters, beginning with observation $t-1$. The lag structures had a mean lag of over five quarters with statistically significant weights extending into the third year. ${ }^{22}$ The lag structure for equation (3) of Table 3 is presented in Table 4.

The long-run coefficients on both $P N F D$ and $P C O N$ were close to unity in all of these quasi reduced-form equations. Only the coefficient of $C P I$ was significantly below unity when entered as a distributed lag. (When the price term was entered without lags, all the coefficients were around 0.5.) The finding of a price coefficient of unity in the best-fitting equations strongly supports the accelerationist view of the inflation process. Accelera-

21. See, for example, Ray C. Fair, "Labor Force Participation, Wage Rates, and Money Illusion," Review of Economics and Statistics, Vol. 53 (May 1971), pp. 164-68; Robert E. Lucas, Jr., and Leonard A. Rapping, "Real Wages, Employment, and Inflation," Journal of Political Economy, Vol. 77 (September/October 1969), pp. 721-54; and Michael L. Wachter, "A Labor Supply Model for Secondary Workers," Review of Economics and Statistics, Vol. 54 (May 1972), pp. 141-51.

22. After specifying the twelve-quarter lag a priori, I did run the PNFD equations using eight- and sixteen-quarter lags. The overall results are largely unchanged. These results on the importance of product prices conform to those found by Gordon, "WagePrice Controls." The markedly higher long-run coefficients for the price terms in the equations estimated over the period ending 1974:2 rather than 1971:2 are another indication of the difficulty in estimating a stable Phillips curve. No attempt has been made to correct for this problem, largely because I am not sure how to accomplish it. Unstable structural relationships suggest limiting forecasting to the near term, especially in a market as institutionally complex as the one for labor. The notion of long-run equilibrium is complicated by the possibility of institutional change as a response to movements in economic variables. 


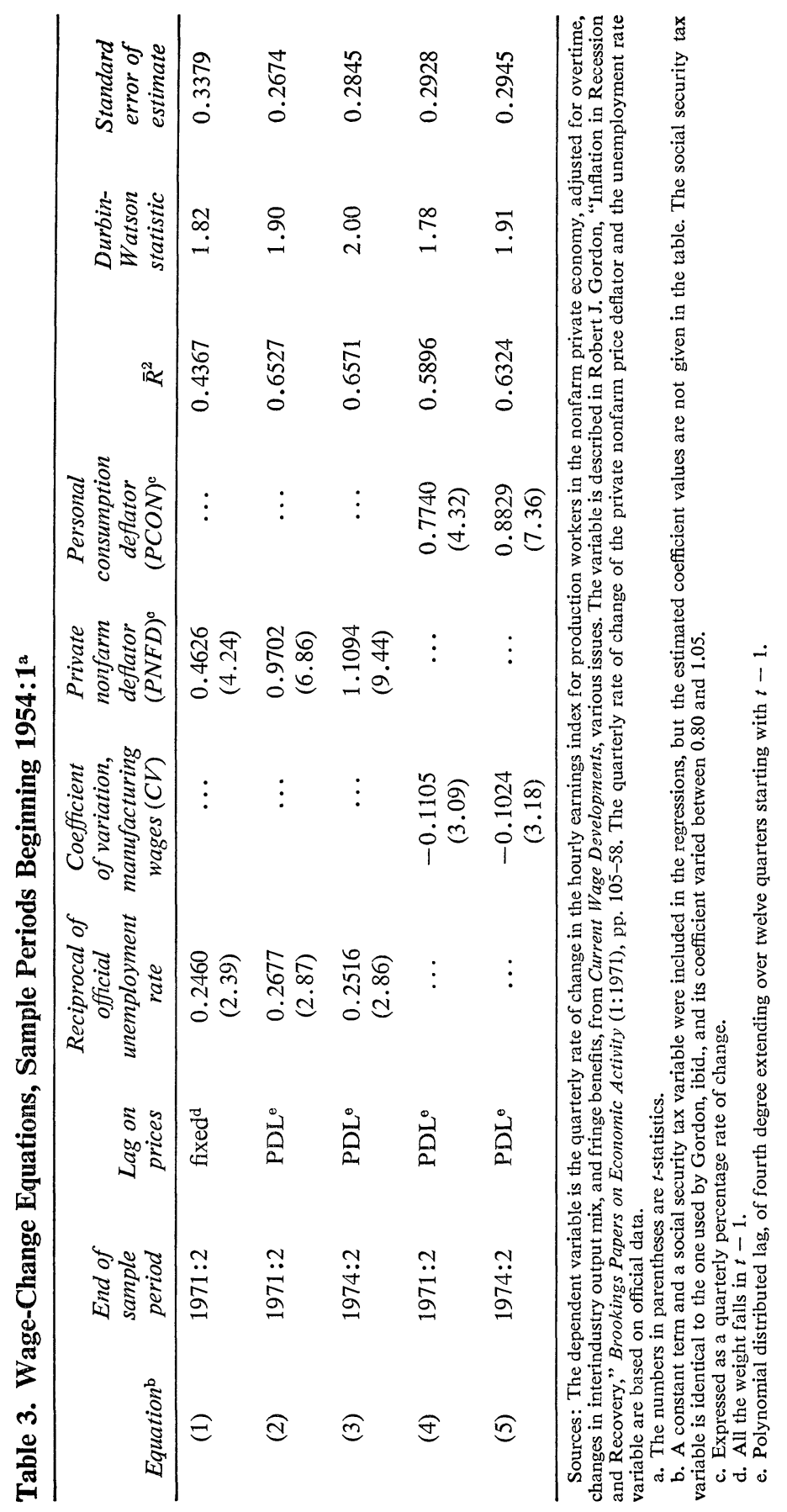


Table 4. Distributed Lag Weights for Private Nonfarm Deflator for Equation (3) of Table 3

\begin{tabular}{lccccc}
\hline Period & Coefficient & $t$-statistic & Period & Coefficient & $t$-statistic \\
\hline$t$ & $\ldots$ & $\ldots$ & $t-7$ & 0.0796 & 3.63 \\
$t-1$ & 0.1889 & 3.03 & $t-8$ & 0.0712 & 3.39 \\
$t-2$ & 0.1577 & 5.18 & $t-9$ & 0.0624 & 2.34 \\
$t-3$ & 0.1333 & 4.86 & $t-10$ & 0.0521 & 1.67 \\
$t-4$ & 0.1144 & 3.49 & $t-11$ & 0.0391 & 1.26 \\
$t-5$ & 0.1000 & 3.04 & $t-12$ & 0.0221 & 1.03 \\
$t-6$ & 0.0889 & 3.18 & & & \\
\hline
\end{tabular}

Source: Derived by author.

tionist findings have also been reported in Gordon's "variable inflation coefficient" and Eckstein-Brinner's "threshold" price constructs. ${ }^{23}$

The official unemployment variable appears in Table 3 in unlagged form. The coefficient of variation is included as an alternative measure of labor market conditions because the results of the $C V$ equations suggest that it can be interpreted as a proxy measure of current and lagged unemployment rates. (The fact that it also includes price effects leads to a reduction in the long-run coefficient of the inflation term whenever $C V$ is included as the labor market variable.) Although no attempt was made to refine this variable to make it more suitable as a labor market proxy, it did perform about as well as the measured unemployment rate in the equations that use $P C O N$ and $C P I$ as the inflation variables. ${ }^{24}$

\section{SIMULATIONS}

Equations estimated for the periods ending 1971:2 and 1974:2 were utilized to forecast future wage developments for alternative predictions of changes in the unemployment and inflation rates. The equations ending with 1971:2 also provide information on the effect of the recent controls program.

23. See Gordon, "Wage-Price Controls"; and Otto Eckstein and Roger Brinner, The Inflation Process in the United States, A Study Prepared for the Use of the Joint Economic Committee, 92 Cong. 2 sess. (1972).

24. Attempts to use the measured unemployment rate with polynomial lags met with mixed success. The question of the lagged response of wages to unemployment deserves further work, especially since the institutional features of the labor market suggest that such lags are important. 
To test for the impact of Phases I through IV, the equations estimated for the period ending 1971:2 were used to simulate the predicted path of wage inflation over the controls period. Since the actual values of the unemployment rate and the rate of inflation were used, the exercise assumes that controls had no impact on unemployment and studies its effect on wages, taking its impact on prices as given. The results suggest that controls did not directly slow the rate of wage change. The residuals of the wage equation for the period 1971:3 to 1974:2 were, in fact, positive on average. If controls did affect wages, they must have worked indirectly by slowing the rate of price inflation. Hence, both the wage inflation and the relativewage equation can explain the 1971-74 period without any reference to a stabilizing influence from wage controls. Consequently, the only postcontrols wage bubble that the economy may suffer through is the indirect one resulting from the decontrolling of prices. This effect through prices could be substantial: in 1974:2, following the end of most Phase IV controls, $P N F D$ increased at an annual rate of 13.6 percent.

Forecasts for the period 1974:3 through 1975:4 are presented in Table 5. The predicted rates of wage inflation are largely the same, especially for 1975 values, whether they are based on equation (2) for the sample period ending 1971:2, or equation (3) extending to $1974: 2$. The actual value of the wage series is approximately 8.75 percent for the final quarter of observed data, 1974:2. As Table 5 demonstrates, both equations forecast a higher rate of wage inflation through 1975:4 for all possible inflationunemployment scenarios. In fact, if only a moderate slowdown develops and inflation slows to an annual rate of 10 percent and the unemployment rate remains below 6 percent until the end of 1975:4, then the rate of wage inflation will rise throughout the forecasted period, reaching an annual rate of over 12 percent by the final quarter. Even in the face of a steep downturn, the wage situation appears bleak. With inflation falling rapidly to an annualized rate of 6 percent by the final quarter of 1975 and the unemployment rate rising to 7 percent, the annual rate of wage inflation, after peaking in 1975:2, is still at 10 percent at the end of 1975 . A question raised by this simulation is whether the rate of inflation is likely to fall to 6 percent if the rate of wage change remains at 10 percent. This consideration suggests that the simulations in the first two banks of Table 5 are likely to be more realistic than the other two. The long lags in the wage process, and the feedback from wages to prices, suggest that wage inflation will exert upward pressure on prices and prevent a rapid descent in the rate of in- 
Table 5. Wage Forecasts for 1974:3-1975:4, under Selected Price and Unemployment Assumptions ${ }^{\mathrm{a}}$

Annual rate of wage inflation in percent

\begin{tabular}{|c|c|c|c|c|c|c|}
\hline Equation & 1974:3 & $1974: 4$ & $1975: 1$ & $1975: 2$ & $1975: 3$ & $1975: 4$ \\
\hline & \multicolumn{6}{|c|}{$\begin{array}{c}\text { Inflation falling rapidly to } 10 \text { percent and unemployment } \\
\text { rising rapidly to } 6 \text { percent }\end{array}$} \\
\hline (2) & 8.40 & 9.72 & 10.76 & 11.56 & 12.00 & 12.24 \\
\hline \multirow[t]{2}{*}{ (3) } & 9.56 & 10.48 & 11.00 & 11.44 & 11.96 & 12.32 \\
\hline & \multicolumn{6}{|c|}{$\begin{array}{c}\text { Inflation falling slowly to } 7 \text { percent and unemployment } \\
\text { rising slowly to } 7 \text { percent }\end{array}$} \\
\hline (2) & 8.40 & 9.72 & 10.72 & 11.32 & 11.48 & 11.24 \\
\hline \multirow[t]{2}{*}{ (3) } & 9.56 & 10.48 & 10.96 & 11.16 & 11.24 & 11.08 \\
\hline & \multicolumn{6}{|c|}{$\begin{array}{l}\text { Inflation falling slowly to } 6 \text { percent and unemployment } \\
\text { rising slowly to } 7 \text { percent }\end{array}$} \\
\hline (2) & 8.40 & 9.72 & 10.76 & 11.24 & 11.12 & 10.72 \\
\hline \multirow[t]{2}{*}{ (3) } & 9.56 & 10.48 & 10.96 & 11.00 & 10.68 & 10.44 \\
\hline & \multicolumn{6}{|c|}{$\begin{array}{c}\text { Inflation falling rapidly to } 6 \text { percent and unemployment } \\
\text { rising slowly to } 7 \text { percent }\end{array}$} \\
\hline (2) & 8.40 & 9.56 & 10.24 & 10.64 & 10.56 & 10.16 \\
\hline (3) & 9.56 & 10.12 & 10.28 & 10.40 & 10.20 & 10.00 \\
\hline
\end{tabular}

Source: Derived by author.

a. Prices are defined by the private nonfarm deflator.

flation. Even if a slowdown does develop, progress in reducing the inflation rate is likely to be very slow through at least the end of 1975 .

\section{Conclusion}

In this paper I have examined wage developments from three perspectives-movements in interindustry wage differentials within the context of a relative-wage equation, wage contract settlements, and overall wage changes as the dependent variable of a Phillips-curve type of equation.

In spite of minor skirmishes and considerable noise-natural trappings of the wage negotiation process-the labor front has been more or less predictable over the period of inflation, 1968-74. Relative-wage equations explain the widening of the wage structure since 1969 as a catchup process as labor market conditions loosened. The recent steel settlement, although generous, was about what could have been expected, given economic conditions at the time. In early 1974 economists and negotiators alike 
were predicting a healthy upswing in the economy beginning in late 1974, and the steel and aluminum businesses were booming.

The evidence strongly suggests the existence of long lags between wage change and its economic determinants. These long lags, which are observable in the relative-wage equation, the nature of contract settlements, and the wage-inflation equation, arise from the interplay of neoclassical market forces in a world with institutional features such as labor unions and oligopolies. Lag weights that are statistically significant more than two years into the past are not surprising, given the existence of labor union contracts, but they have not received sufficient attention in the literature. ${ }^{25}$

The outlook for wage inflation for the remainder of 1974 and 1975 appears grim. Given the range of forecasts of inflation and unemployment now available, the equations of Table 3 indicate that the rate of wage change will be higher at the end of 1975 than it is at present. Indeed, even if a significant downturn develops, wage inflation is predicted to be at approximately 10 percent through 1975:4. This short-term rigidity in the rate of money-wage change, which is based on the long lags in the wage equation, should hinder any significant slowing in the rate of price inflation. The resulting gain in real wages, as predicted by the relative-wage equation, will accrue largely to the unionized sector as a result of the recent contract settlements. Because of lags, labor, which often appears to be the hero during expansions, will appear to be the villain again in the next contraction.

\section{Discussion}

Joseph Pechman and R. J. Gordon were inclined to place more emphasis than Wachter did on wage-price controls in explaining the recent history of wages. Pechman called attention to the modest settlements of 1972 and

25. A major exception is the work of Otto Eckstein and Thomas A. Wilson, "The Determination of Money Wages in American Industry," Quarterly Journal of Economics, Vol. 76 (August 1962), pp. 379-414. They recognized the lags in the labor market and the importance of using the wage round as the observation period. Unfortunately, their insights were largely neglected when the profession moved to the quarterly models needed for forecasting purposes. More recent work on lags includes Gordon, "Inflation in Recession and Recovery," and "Wage-Price Controls." 
1973 (as shown in Wachter's Table 1), sandwiched between rapid increases in 1969-71 and in 1974; he viewed that record as evidence that Phases I and II had had some effect. Wachter thought the moderate size of the settlements of 1972 and 1973 might be misleading. The decrease in wage settlements during the controls period was far more pronounced in first-year changes than in life-of-contract changes. Wachter suggested that the front loading of contract settlements could be indicative of a catch-up effect. Gordon stressed the role of price controls in stiffening employer resistance to large wage increases.

Several participants commented on the presence of product prices rather than consumer prices in Wachter's preferred wage equation. While agreeing that consumer prices could also play a role from the supply side in determining wages, some were glad to see product prices (as measured by the private nonfarm deflator) come through as an important element in the demand curve for labor. R. A. Gordon suggested that product prices may serve a dual function in the equation, reflecting both the cost of living to workers and the profitability of firms. Robert Hall saw product prices as the price of value added, or something close to wages themselves. This squared with his view of a wage-wage, rather than a wage-price, spiral.

Franco Modigliani thought Wachter was going beyond his empirical results in explaining wages in terms of the expectations of unions. None of Wachter's equations incorporates expectations and yet they all perform quite well in explaining the coefficient of variation of wages. Modigliani preferred to interpret the variation in the gap between union and nonunion wages as the result of the different reactions the two sectors have to unemployment and inflation. Union wages reflect inflation more and unemployment less than do nonunionized wages, according to Modigliani's own empirical research.

Interpreting Wachter's results in terms of the concepts of his own paper, Hall felt that the scale wage was interpreted as if it were the effective wage. In the event of recession or boom, the two might diverge markedly.

R. J. Gordon pointed to the considerable increase in the coefficient of the price-change variable in the wage equations over the last three years. In his judgment, this development called into question any econometric model that assumes constant coefficients since 1954. 